\section{DIGITAL COMMONS \\ @ UNIVERSITY OF SOUTH FLORIDA}

\section{ABO: Interactive Journal for Women in the Arts, 1640-1830}

\title{
A Political Biography of Eliza Haywood, by Kathryn R. King
}

Kristin M. Girten

University of Nebraska, Omaha, kgirten@unomaha.edu

Follow this and additional works at: https://digitalcommons.usf.edu/abo

Part of the Dramatic Literature, Criticism and Theory Commons, Educational Methods Commons, Feminist, Gender, and Sexuality Studies Commons, and the Literature in English, British Isles Commons

\section{Recommended Citation}

Girten, Kristin M. (2013) "A Political Biography of Eliza Haywood, by Kathryn R. King," ABO: Interactive Journal for Women in the Arts, 1640-1830: Vol.3: Iss.1, Article 10.

http://dx.doi.org/10.5038/2157-7129.3.1.10

Available at: https://digitalcommons.usf.edu/abo/vol3/iss1/10

This Reviews is brought to you for free and open access by Digital Commons @ University of South Florida. It has been accepted for inclusion in ABO: Interactive Journal for Women in the Arts, 1640-1830 by an authorized administrator of Digital Commons @ University of South Florida. For more information, please contact digitalcommons@usf.edu. 


\section{A Political Biography of Eliza Haywood, by Kathryn R. King}

\section{Keywords}

Eliza Haywood, British periodical, Tory feminism, Jacobitism, eighteenth-century political history, women's literary history, women's political history, political biography

\section{Creative Commons License}

\section{(c) (1) $\odot$}

This work is licensed under a Creative Commons Attribution-No Derivative Works 3.0 License. 
Kathryn R. King. A Political Biography of Eliza Haywood. London: Pickering and Chatto, 2012. \$99.00. Xii + 267pp. ISBN: 9781851969173.

Reviewed by Kristin M. Girten, University of Nebraska, Omaha

With A Political Biography of Eliza Haywood, Kathryn R. King takes her reader on a pioneering expedition throughout Haywood's various and regularly contradictory literary-political career. Proceeding from Haywood's early days as an actress at the Smock Alley Theatre in Dublin through the publication of her last significant political work, The Invisible Spy, King manages to cover a great amount of terrain. However, while the scope of King's biography is impressive, even more so is the depth with which it interrogates scholarly assumptions about key works by Haywood and significant details of her life. The result of King's unflagging excavation is a set of discoveries that have important implications not only for Haywood scholarship but also for the history of eighteenth-century British politics. With A Political Biography of Eliza Haywood, King presents a challenge to how scholars typically perceive both Haywood's political affinities as well as the nature of her literary career. She counters the tendency of scholarship to associate Haywood with Tory ideology and Jacobitism, presenting convincing evidence that the author's politics cannot be so easily categorized. Additionally, she opens up a new window into eighteenth-century opposition politics that contests the scholarly tendency to separate "high" and "low" political activity. From the biographical details and textual features that King illuminates, it becomes apparent that, though Haywood is rightly associated with Grub Street and thus the "low" end of politics, there is credible evidence that she also engaged in higher levels of political discourse, specifically through relationships she maintained, if not personally then textually, with the Country Party opposition and the Leicester House faction.

As King notes, recent Haywood scholarship has rightly put to rest the once dominant impression that, in response to Pope's unflattering depiction of her in The Dunciad (1728), Haywood's career took a drastic turn away from the freedom of her early amatory work towards didactic moralism. However, she makes an insightful point when she indicates that scholars have had the tendency to replace this linear narrative with others-specifically, by "find[ing] didacticism in the early works, say, or subversive tendencies in the purportedly conservative later work" (195). In this biography, Haywood emerges as "a mistress of multiplicity," causing King ultimately to suggest that "it may be necessary to do away with linearity altogether in the case of Haywood" (195). In fact, this is precisely what King herself does. Readers of the biography looking for a story of linear consistency or development will be surprised, if not somewhat disappointed, to find little continuity or coherence in the life and work of Haywood. Rather, what emerges is a life and body of work distinguished by a set of recurring themes and characteristics whose recurrence regularly lacks a clear underlying rationale. For a less adept scholar, such a lack may suggest a weakness in the research informing the study. However, the opposite is the case with King's biography. It is the strength of her research that allows her to bring the variability of Haywood's life and work to light. Expressing a firm commitment to taking the intricacies of Haywood's life and work on their own terms, King refuses to impose an explanatory or organizational structure when the evidence reveals that such a structure is unwarranted. In King's portrayal, Haywood is at times friendly to the Jacobite cause, at other times a voice for Patriot principles, and at still others a proponent of Whiggish attitudes. King cultivates a flexible method by which to depict Haywood in response to the fluidity and variability of Haywood herself. King 
writes that "Haywood consistently aligned herself with those excluded from or out of power," but since the groups "out of power" shifted considerably throughout her adult life, so did Haywood's allegiances (7).

However, while King generally denies linear consistency within Haywood's biography, one constant nevertheless emerges as the story unfolds: feminism. King repeatedly emphasizes feminist elements within Haywood's works, often connecting these elements to biographical details. In fact, so regularly do such elements surface that it is surprising that they do not contribute more to the book's frame. In the Introduction, King indicates that “ . . p party political labels like Whig, Tory and Jacobite recede in importance when Haywood is contemplated within the feminist-inflected Enlightenment contexts that are reconstructed in some detail in this book" (10). This statement invites the reader to expect that Haywood's relationship with feminism will organize and guide the chapters to follow. Instead, though, this relationship typically rises to the surface only in passing. Consequently, in the end, readers are left wondering how exactly Haywood's persistent feminism relates to her shifting political allegiances. Another statement King makes in the Introduction hints at an answer to this question: "Haywood is rightly admired for her penetrating if somewhat cynical analyses of the skills needed by women to survive in a world that favours men in virtually every way. It is satisfying to discover that in addition she worked out for herself a vision of women's productive role in national public life more richly imagined than I could have predicted before beginning this study" (10). The feminist industriousness that King here associates with Haywood suggests that Haywood's feminism may be responsible for the variability of her political affinities. One wonders if perhaps her feminist drive "to survive" inspires her political flexibility: to maintain a "productive" public persona, particularly in such politically volatile times, Haywood may have felt compelled to shift in response to political and social shifts. King's biography misses an important opportunity by neglecting to provide a fuller exploration of this implication. In fact, too frequently throughout the biography, King's application of "feminist" to Haywood is unsatisfying. She employs the term in various contexts and to signify various aspects of her life and writing. Lacking a clear overarching theory of Haywood's feminism, though, such variability in application is confusing. Moreover, and more significantly, it also undermines the meaningfulness of the term. Particularly given its anachronistic status, for the term to be used effectively to apply to such a mercurial subject as Haywood, its definition needs to be established with great precision. Too often, King's use of the term feels too much like an instance of shorthand rather than an insightful characterization. However, perhaps the most exciting feature of King's Political Biography of Eliza Haywood is its success at opening up promising new areas of research, and one such area is most certainly the connection between the feminist qualities of Haywood's writings and her political affinities. King may not do enough to illuminate this connection herself, but she undoubtedly helps prepare the ground for other scholars to do so.

The discoveries King makes, in combination with her more tentative speculations, will have an energizing effect on Haywood scholarship. As a result of King's careful and insightful scholarship, we can expect to see refreshed interest in Haywood's acting career, her work as a publisher under the sign of Fame, her scandal fiction, the Goring pamphlet, Adventures of Eovaii, The Female Spectator, The Parrot, and Epistles for the Ladies. King inspires scholars to recognize that political meanings and even messages are woven throughout a great portion of Haywood's life and writing. To read for the political within Haywood's performances and 
publications even when they seem, at least superficially, removed from political discourse is to bring new dimensions to light within not only Haywood's works but also the complex political landscape of eighteenth-century Britain. 